\title{
Blood homocysteine, folic acid, vitamin B12 and vitamin B6 levels in psoriasis patients
}

\section{Psoriazis hastalarında kan homosistein, folik asit, vitamin B12 ve vitamin B6 düzeyleri}

\section{Meltem Uslu, Neslihan Șendur, Ekin Șavk, Aslıhan Karul*, Didem Kozacı*, Cengiz Gökbulut**, Göksun Karaman, İmran Kurt Ömürlü***}

\begin{abstract}
Adnan Menderes University Faculty of Medicine, Department of Dermatology, *Department of Biochemistry, Aydın, Turkey **Adnan Menderes University Veterinary Faculty, Department of Pharmacology Toxicology, Aydın, Turkey
\end{abstract} ***Adnan Menderes University Faculty of Medicine, Department of Biostatistics and Medical Informatics, Aydın, Turkey

\begin{abstract}
Background and Design: Homocysteine, a sulfur-containing amino acid, is known to be related with autoimmunity-inflammation, cardiovascular disease and DNA methylation. In this case-control study, we aimed to determine plasma homocysteine, folic acid, vitamin B12 and vitamin B6 levels in patients with psoriasis.

Materials and Methods: Smoking, alcohol and coffee consumption habits were recorded in adult patients with plaque-type psoriasis and age- and sex-matched controls. Height and weight measurements were performed and Psoriasis Area and Severity Index (PASI) scores were calculated. Fasting venous blood samples were collected to determine homocysteine, folic acid, vitamin B12, vitamin B6, glucose, total cholesterol, triglyceride, high density lipoprotein (HDL), erythrocyte sedimentation rate (ESR), and C-reactive protein (CRP) levels.

Results: There was no significant difference between psoriasis patients $(n=43)$ and controls $(n=47)$ in body mass index and alcohol and coffee consumption. Smoking rate was significantly high in psoriasis patients. The median PASI score was 10.0 (8.3-12.8). Plasma homocysteine, folic acid, vitamin B12, vitamin B6, total cholesterol, triglyseride, ESR and CRP values were not significantly different between patients and the controls. HDL level was low in psoriasis patients $(p=0.001)$. Plasma homocysteine level was higher in males than in females. There was no relationship of homocysteine levels with patient's age, PASI scores, ESR, CRP values and lipids. Homocysteine levels were inversely related with folic acid and vitamin B12 ( $p=0.000, r=-0.436, p=0.047, r=-0.204$, respectively). We did not find any relationship between homocysteine and vitamin B6 levels.

Conclusion: There was no increase in plasma homocysteine levels in psoriasis patients we followed up. Homocysteine level increases in inflammatory disorders and this increase is accepted as a cardiovascular disease marker. Homocysteine homeostasis may be balanced in our patients because of the genetic background and/or nutritional habits in this population
\end{abstract}

Keywords: Psoriasis, homocysteine, folic acid

Öz

Amaç: Homosistein kardiyovasküler hastalık, otoimmünite-enflamasyon ve DNA metilasyonu ile ilişkilendirilen sülfür içeren bir aminoasittir Bu olgu-kontrol çalışmasında psoriazisli hastalarda plazma homosistein düzeylerinin ve homosisteini etkileyen folik asit, vitamin B6 ve vitamin B12 düzeylerinin belirlenmesi amaçlanmışıır.

Gereç ve Yöntem: Polikliniğimizde takip edilen erişkin plak tip psoriazis hastaları ile yaş ve cinsiyet uyumlu kontrol grubunda alkol, kahve ve sigara tüketimi sorgulandı, katııımıların boy ve ağırlıkları ölçüldü. Hastaların Psoriazis Alan Şiddet İndeksleri (PAŞi) hesaplandı. Sabah açlık kan örnekleri alınarak homosistein, folik asit, vitamin B12, vitamin B6, kan şekeri, serum total kolesterol, trigliserid, yüksek yoğunluklu lipoproteinler (HDL), eritrosit sedimantasyon hızı (ESH) ve C-reaktif protein (CRP) değerleri çalışıldı.

Bulgular: Psoriazisli hasta $(n=43)$ ve kontrol grubu $(n=47)$ arasında vücut kitle indeksi, alkol tüketimi ve kahve tüketimi açısından anlaml farklılık yoktu. Medyan PAŞi 10,0 (8,3-12,8) idi. Sigara kullanan kişi oranı psoriazisli hastalarda anlamlı yüksekti. Psoriazisli hastalar ile kontrol gurubu arasında plazma homosistein, folik asit, vitamin B12, vitamin B6, total kolesterol, trigliserid, ESH ve CRP değerleri açısından anlaml farklıık olmadığı görüldü. HDL-kolesterol düzeyi hasta grubunda daha düşüktü $(p=0,001)$. Serum homosistein düzeyi erkeklerde kadınlara göre daha yüksek saptandı $(p=0,014)$. Serum homosistein düzeyi ile katılımcıların yaşı, PAŞi, ESH, CRP ve lipid değerleri arasında herhangi

Address for Correspondence/Yazışma Adresi: Meltem Uslu MD, Adnan Menderes University Faculty of Medicine, Department of Dermatology, Aydın, Turkey Phone.: +90 5056815964 E-mail: meltemozdogan@msn.com ORCID-ID: orcid.org/0000-0002-8322-0812 Received/Geliş Tarihi: 13.03.2017 Accepted/Kabul Tarihi: 15.06.2017

C) Copyright 2017 by Turkish Society of Dermatology and Venereology

Turkderm-Turkish Archives of Dermatology and Venereology published by Galenos Yayınevi. 
bir ilişki saptanmadı. Homosistein düzeyi ile folik asit ve vitamin B12 arasında ters ilişki vardı (sırasıyla $p=0,000, r=-0,436, p=0,047, r=-0,204$ ). Homosistein ile vitamin B6 arasında ilişki saptanmadı.

Sonuç: İzlemimizdeki psoriazis hastalarında plazma homosistein yüksekliği görülmemiştir. Enflamatuvar hastalıklarda yüksek düzeyde saptanan ve yüksekliği kardiyovasküler hastalık risk belirteci kabul edilen homosistein, bu hasta popülasyonunda genetik ve/veya beslenmeyle ilişkili özelliklerden dolayı dengede tutulmuş olabilir.

Anahtar Kelimeler: Psoriazis, homosistein, folik asit

\section{Introduction}

Psoriasis is a multifactorial inflammatory skin disease, which is assumed to be T-cell-mediated and to result from a polygenic predisposition. It is characterized by hyperproliferation and poor differentiation of epidermal keratinocytes. Many studies conducted in recent years have shown that psoriatic patients, especially those with severe psoriasis, have increased risk of cardiovascular disease (CVD) and mortality associated with $C V D^{1-3}$. The usual CVD risk factors, such as metabolic syndrome, smoking, and alcohol consumption that often accompany psoriasis, the lipid-(cyclosporin and acitretin) and homocysteineelevating (methotrexate) effects of the drugs used for treating psoriasis, and inflammation in the pathogenesis of psoriasis that show apparent parallelism with atherosclerosis are thought to contribute to this predisposition ${ }^{4,5}$. After the studies made in 1990s where high levels of homocysteine were found in plasma samples of subjects who had or would likely to have a history of myocardial infarction, ischemic stroke or peripheral vascular disease and the association of homocysteine with atherosclerosis and hypercoagulability had been shown $n^{6-12}$, along with increased attention to the comorbidities of psoriasis, as far as we know, 19 studies have been conducted to explore homocysteine levels in these patients. Homocysteine level was found to be high in 12 and normal in 7 of these studies ${ }^{13-31}$.

Since this sulfur-containing amino acid is not taken through diet and not producing protein, homocysteine is formed via methionine catabolism $^{8,11,27}$. Homocysteine is formed by demethylation of methionine, which is abundant in animal protein and is the core determinant of the methylation cycle ${ }^{11,32}$. Homocysteine is metabolized through two pathways: One of these is the remethylation cycle where homocysteine is reconverted into methionine. Folic acid and vitamin B12 serve as cofactors in this cycle where DNA methylation takes place simultaneously. This pathway has the potential of playing a role in the pathogenesis of psoriasis regarding that DNA methylation affects the gene regulation and cell differentiation ${ }^{33,34}$. The other pathway is the transsulphuration where homocysteine is converted into cystathionine with the mediation of vitamine $\mathrm{B}^{32}$. Besides $\mathrm{CVD}$, other conditions causing or accompanying hyperhomocysteinemia include folate, vitamin B6 and vitamin B12 deficiencies associated with poor dietary intake as well as, smoking, alcohol and coffee consumption, advanced age, menopause, renal failure, autoimmune diseases, diabetes mellitus, osteoporosis, neuropsychiatric disorders, cancer, thyroid diseases, birth defects, and various medications $s^{6,11,35}$. Conditions causing elevated homocysteine include genetic defects of enzymes such as methylenetetrahydrofolate reductase (MTHFR), methionine synthase and cystathionine $\beta$ synthase ${ }^{11}$. The most common defect seen worldwide is mild or moderate hyperhomocysteinemia accompanied by single nucleotide polymorphism in the MTHFR enzyme, which has been found to be associated with psoriasis in some studies $s^{6,11,36,37}$.

Since plasma homocysteine level is affected by eating habits ${ }^{38}$ and the genetic polymorphisms of the enzymes involved in its metabolism differ depending on the geographic region and ethnicity ${ }^{15}$, we aimed at investigating plasma homocysteine and homocysteine-related vitamin levels in psoriatic patients living in our region.

\section{Materials and Methods}

Patients with plaque psoriasis, who attended our outpatient clinic, were included in the study. Dermatology outpatient clinic patients, hospital staff and patient relatives who had no psoriasis constituted the control group. Those who received systemic treatment for psoriasis in the past one month, were known to have a liver, kidney or thyroid disease, and those with a history of an autoimmune disorder, diabetes mellitus or malignancy as well as those who used drugs (thiazide diuretics, penicillamine, theophylline, oral contraceptives, azathioprine, metformin and anticonvulsants) and vitamins that are known to elevate homocysteine were excluded from the study. Participant information on age, gender, duration of disease and, alcohol and coffee drinking habits was recorded; height and weight of the subjects were measured to calculate body mass index (BMI). The severity of the disease was calculated using the Psoriasis Area and Severity Index (PASI). Fasting blood samples were taken from all participants in the morning and homocysteine levels were measured by using the High Performance Liquid Chromatography method. Plasma folate, vitamin B12 and vitamin B6 levels as well as fasting blood glucose (FBG), serum total cholesterol, triglyceride, high density lipoprotein (HDL), thyroid stimulating hormone (TSH), urea, creatinine, complete blood count, erythrocyte sedimentation rate (ESR) and C-reactive protein (CRP) values were determined. Local ethics committee approval was obtained for the study.

\section{Statistical analysis}

In the statistical analysis, whether the quantitative data had a normal distribution was explored using the Kolmogorov-Smirnov test. The t-test was used in intergroup comparisons of the independent groups for normally distributed variables and the descriptive statistics were shown as mean \pm standard deviation. The Mann-Whitney $U$ test was used for intergroup comparisons of the variables not showing a normal distribution and the descriptive statistics were given as medians (25-75 percentiles). The qualitative data were analyzed with the chi-square test and the descriptive statistics were shown as $n(\%)$. The relationships between the variables were assessed using Spearman's correlation coefficient. A p value of less than 0.05 was considered statistically significant.

\section{Results}

The study included 50 psoriatic patients and 48 controls. Forty-six of the 98 participants were female and 52 were male with the mean age of $37.1 \pm 12.5$ (18-73) years. The mean BMl of the subjects was 25.7 \pm 4.9 (range: 17.3-38.2). There was no significant difference in BMI between the patient and control groups (Table 1). Coffee and alcohol consumption habits of the patient and control groups were similar, but the rate of smoking was significantly higher in the psoriatic patient 
group compared to that in the control group (Table 1). The median PASI value in the patients was 10.0 (range: 1.4-37.5).

Assessment of the patients' biochemical parameters showed that none of the participants had any findings of renal disease or hematological malignancy that would influence homocysteine levels. Four psoriatic patients had high FBG and three had high TSH; whereas one subject in the control group had a high level of TSH.

Folic acid level was below normal $(<3 \mathrm{ng} / \mathrm{mL})$ in 2 subjects in the control group. Vitamin B6 level was within the normal values in all participants. Vitamin B12 level was below normal $(<193 \mathrm{pg} / \mathrm{mL})$ in 18 persons (36\%) in the patient group and 20 subjects $(42.6 \%)$ in the control group. A high homocysteine level (>15 $\mu \mathrm{mol} / \mathrm{L}$ ) was found in 12 persons (28.6\%) in the patient group and in $13(27.3 \%)$ in the control group. The analysis made for excluding participants with abnormal FBG and TSH levels showed that there was no statistically significant difference in plasma homocysteine, folic acid, vitamin B12, vitamin B6, total cholesterol, triglyceride, ESR and CRP values between the psoriasis group and the control group. HDL-cholesterol level was statistically significantly lower in the patient group (Table 2). Serum homocysteine level was found to be significantly higher in males $(16.6 \pm 4.6 \mu \mathrm{mol} / \mathrm{L})$ than in females $(13.2 \pm 3.9 \mu \mathrm{mol} / \mathrm{L})(p=0.014)$. No correlation of homocysteine level with the age of the participants and PASI, ESR, CRP, and lipid values $(p \geq 0.05)$. There was a reverse and moderate correlation between homocysteine level and folic acid ( $p=0.000, r=0.436)$ and a reverse and weak correlation between homocysteine level and vitamin $B 12$ ( $p=0.047, r=0.204)$. No correlation was found between the levels of homocysteine and vitamin $B 6(p \geq 0.05)$.

\section{Discussion}

The prevalence of hyperhomocysteinemia in the general population is $5 \%{ }^{35}$. One of the congenital causes of high homocysteine is homocystinuria that occurs as a result of cystathionine $\beta$ synthase defect and its incidence is $1: 200.000$. If not treated, at least half of patients with severe hyperhomocysteinemia (>100 $\mu \mathrm{mol} / \mathrm{L})$ will develop thromboembolic events and a resulting CVD in their childhood or adolescence with increased mortality at an early age ${ }^{39}$. In view of this and other observations, McCully introduced in 1969 the homocysteine theory of atherosclerosis ${ }^{12}$. Vascular endothelium has a vital role in establishing the balance between pro- and anti-coagulant factors and

\section{Table 1. Clinic characteristics of participants}

\begin{tabular}{|l|l|l|l|}
\hline & Patients & Controls & $p$ \\
\hline Age & $37.8 \pm 13.2$ & $36.4 \pm 11.8$ & 0.494 \\
\hline Gender & $21 / 29(\mathrm{~F} / \mathrm{M})$ & $25 / 23(\mathrm{~F} / \mathrm{M})$ & 0.230 \\
\hline BMI & $26.5 \pm 5.2$ & $25.0 \pm 4.4$ & 0.177 \\
\hline Rate of smoking & $50.0 \%$ & $11.4 \%$ & $<0.001$ \\
\hline Rate of using alcohol & $19.6 \%$ & $18.2 \%$ & 0.867 \\
\hline $\begin{array}{l}\text { Coffee } \\
\text { (Number of cups a week) }\end{array}$ & $1(0.25-2)$ & $1(0.25-1)$ & 0.169 \\
\hline PASI & $10.0(8.3-12.8)$ & & \\
\hline F: Female, M: Male, BMI: Body mass index, PASI: Psoriasis Area and Severity Index \\
\hline
\end{tabular}

various studies have shown that high levels of homocysteine cause endothelium dysfunction leading to tendency to develop thrombosis, vasodilatation response disorder and cytotoxic effect in endothelium ${ }^{12}$. Studies are being carried out in recent years to reveal whether or not high homocysteine contributes to atherogenesis through DNA hypomethylation ${ }^{35}$.

Besides atherogenesis, homocysteine is also linked to inflammation and autoimmunity. With its ability to bind to special proteins and to modify them, homocysteine may cause formation of new antigens. There is growing evidence that hyperhomocysteinemia not only represents a risk factor for the development of CVD accompanying inflammatory and autoimmune diseases, but also plays a role in the onset and progression of tissue damage underlying the disease ${ }^{40}$. Homocysteine and its various derivatives have been shown, depending on their concentration, to activate $T$ cells or cause their apoptosis. Stimulation of mononuclear cells or isolated $T$ cells in the presence of homocysteine results in an apparent increase of type 1 cytokines such as interleukin (IL)-2, interferon- $\gamma$, tumor necrosis factor- $\alpha$ and IL-10, but not type 2 cytokines such as IL-4 and IL-5 ${ }^{41}$. Production of homocysteine is associated with proliferating activity of peripheral blood mononuclear cells ${ }^{42}$. Elevation of homocysteine in rheumatoid arthritis, inflammatory bowel disease and Behçet's disease go hand in hand with the elevation of some inflammatory markers and there are evidences that homocysteine plays an immuno-inflammatory activation triggering and/or aggravating role in these diseases ${ }^{40}$. In brief, homocysteine is an amino acid, the blood level of which is elevated through immuno-inflammatory activation and which can also cause immuno-inflammatory activation itself initiating autoimmune diseases ${ }^{40}$. In psoriasis, also an inflammatory disease, homocysteinerelated pathogenetic studies are about the DNA methylation which occurs during the homocysteine transformation into methionine. DNA methylation is a leading epigenetic factor that is thought to be responsible for the pathogenesis of psoriasis ${ }^{33}$. "Epigenetic" represents the factors that cause changes in phenotype through modification of gene functioning without a change in gene sequence. This concept can

\begin{tabular}{|c|c|c|c|}
\hline & Psoriasis & Control & $\mathbf{p}$ \\
\hline $\begin{array}{l}\text { Homocysteine } \\
(\mu \mathrm{mol} / \mathrm{L})\end{array}$ & $13.0(10.5-14.9)$ & $14.0(12.3-18.8)$ & 0.231 \\
\hline $\begin{array}{l}\text { Folic acid } \\
(\mathrm{ng} / \mathrm{mL})\end{array}$ & $7.7 \pm 2.6$ & $6.6 \pm 2.9$ & 0.740 \\
\hline $\begin{array}{l}\text { Vitamin B12 } \\
(\mathrm{pg} / \mathrm{mL})\end{array}$ & $253.1 \pm 116.2$ & $230.1 \pm 83.4$ & 0.214 \\
\hline $\begin{array}{l}\text { Vitamin B6 } \\
(\mu \mathrm{g} / \mathrm{L})\end{array}$ & $14.6(14.2-19.2)$ & $17.0(14.3-22.2)$ & 0.081 \\
\hline $\begin{array}{l}\text { HDL-cholesterol } \\
(\mathrm{mg} / \mathrm{dL})\end{array}$ & $42.7 \pm 10.5$ & $50.4 \pm 11.9$ & 0.001 \\
\hline $\begin{array}{l}\text { Cholesterol } \\
(\mathrm{mg} / \mathrm{dL})\end{array}$ & $175.5(157.5-211.0)$ & $184.0(160.7-217.2)$ & 0.820 \\
\hline $\begin{array}{l}\text { Triglyceride } \\
(\mathrm{mg} / \mathrm{dL})\end{array}$ & $102.0(72.5-142.0)$ & $80.0(60.5-121.2)$ & 0.089 \\
\hline ESR & $24.0(10.0-29.0)$ & $13.0(10.0-25.0)$ & 0.129 \\
\hline CRP (mg/L) & $1.23(0.2-3.1)$ & $1.13(0.5-2.8)$ & 0.952 \\
\hline \multicolumn{4}{|c|}{$\begin{array}{l}\text { HDL: High density lipoprotein, ESR: Erythrocyte sedimentation rate, CRP: C-reactive } \\
\text { protein }\end{array}$} \\
\hline
\end{tabular}


explain the reason why, for instance, psoriasis develops in one of the monozygotic twins and does not in the other although they both have the same genetic and similar environmental factors. There have been studies demonstrating various genes in cells in the epidermis, blood or bone marrow were less or more methylated in patients with psoriasis compared to that in controls. Some of these genes are associated with proliferation and differentiation ${ }^{33}$. Therefore, in diseases accompanying high homocysteine and DNA methylation disorder may be a part of the process ${ }^{32}$.

Contrary to the data supporting the possibility of homocysteine being involved in the pathogenesis of psoriasis, no difference was found in our study between the psoriatic patients and controls in the plasma homocysteine level or the folic acid, vitamin B12 and vitamin B6 values that affect the homocysteine level. In addition, there was no correlation between disease severity and the level of homocysteine. Similar to our results, blood homocysteine values were shown to remain unaffected by psoriasis also in five studies conducted in our country as well as in various studies in Spain and Malaysia (Table 3) $)^{13-}$ 19. However, unlike these results, patients with psoriasis were found to have high blood homocysteine in other five studies again in our country and five in Italy and one each in Ireland and Norway ${ }^{20-31}$. In the literature, studies showing psoriasis being accompanied by high blood homocysteine seem to be predominant (Table 3). The reason for this coexistence is still not fully understood, but one of the propositions is that fast keratinocyte proliferation in psoriasis increases folic acid consumption or microinflammation accompanying psoriasis in colonic mucosa ${ }^{43,44}$ reduces folic acid absorption leading to folic acid deficiency which results in elevation of homocysteine ${ }^{25,26}$. No folic acid deficiency was found in psoriatic patients in this study, but as in many other studies, we observed a reverse correlation between folic acid and homocysteine ${ }^{11,21}$. When the studies investigating homocysteine in psoriasis are reviewed in this sense, a statistically significant folic acid deficiency accompanying the condition was seen in seven of nine studies where high homocysteine was found and an insignificant deficiency in one. Normal folic acid was found in only 1 of this 8 studies. Therefore, high homocysteine in psoriasis seems to have a parallel course to folic acid deficiency, and as mentioned shortly before, high homocysteine may be found secondary to folic acid deficiency. In a study by Refsum et al. ${ }^{31}$ where high homocysteine in psoriasis was first detected as far as we know, it was reported that methotrexate therapy temporarily caused elevation of homocysteine after each dose; hence, elevation of homocysteine was considered a sensitive indicator of antifolate effect of methotrexate therapy. Homocysteine was observed to go down to its pre-dose level during dose intervals in that study. A decrease in homocysteine observed after a high dose of methotrexate therapy given to cancer patients have been explained by the folic acid rescue therapy given after this therapy or by homocysteine secreted from highly proliferated cells being rapidly lost as a result of cytotoxic drug effect ${ }^{31}$. Folic acid is a water-soluble vitamin that perishes under high heat; it is found naturally in a large variety of foods including spinach, cabbage, broccoli sprouts, beans, legumes, meat, poultry, yeast, oranges, wheat bran and whole grains ${ }^{45}$. One of the speculative explanations for not encountering high levels of homocysteine in psoriatic patients in our region may be that they meet their need for large amounts of folic acid through their habit of consuming an abundance of vegetables

Table 3. Studies where plasma homocysteine levels are explored in patients with psoriasis

\begin{tabular}{|c|c|c|c|c|c|c|c|c|c|c|c|c|}
\hline & $\mathrm{Hc}$ & B12 & Fol & Pso/C & CVD & PASI & $\mathrm{S}-\mathrm{Cr}$ & DM & HT & BMI & $\mathrm{DL}$ & $\mathrm{Sm}$ \\
\hline Gaziantep (13) & $=$ & $\varnothing$ & $\varnothing$ & $50 / 40$ & $+/-$ & 20.3 & $\varnothing$ & $=$ & $\uparrow$ & $=$ & $=$ & $\varnothing$ \\
\hline Isparta (14) & $=$ & $\varnothing$ & $\varnothing$ & $56 / 53$ & - & 6.1 & - & - & - & $=$ & $\uparrow$ & $=$ \\
\hline Spain (16) & $=$ & $\varnothing$ & $\varnothing$ & $50 / 50$ & $+/-$ & 15.6 & $\varnothing$ & $=$ & $=$ & $=$ & $\uparrow$ & $=$ \\
\hline Konya (17) & $=$ & $\varnothing$ & $\varnothing$ & $56 / 33$ & $+/-$ & 8.3 & + & - & - & $=$ & $\varnothing$ & - \\
\hline The present study & $=$ & $=$ & $=$ & $43 / 47$ & $+/-$ & 10.0 & - & - & $\varnothing$ & $=$ & $\uparrow$ & $\uparrow$ \\
\hline İstanbul (20) & $\uparrow$ & $\mathrm{N}$ & $\downarrow$ & $60 /-$ & - & 7.2 & - & $\varnothing$ & $\varnothing$ & $\varnothing$ & $\varnothing$ & $\varnothing$ \\
\hline İstanbul (21) & $\uparrow$ & $=$ & $\downarrow$ & $20 / 20$ & - & 13.7 & + & - & - & $=$ & - & $\varnothing$ \\
\hline Trabzon (22) & $\uparrow$ & $\downarrow$ & $\downarrow$ & $30 / 30$ & $+/-$ & 5.5 & - & $\varnothing$ & $\varnothing$ & $\varnothing$ & $\uparrow$ & - \\
\hline Italy (26) & $\uparrow$ & $=$ & $\downarrow$ & $40 / 30$ & - & 9.8 & + & - & $\varnothing$ & $=$ & $\varnothing$ & - \\
\hline Italy (27) & $\uparrow$ & $\downarrow$ & $\downarrow$ & $98 / 98$ & $+/-$ & 20 & - & $\varnothing$ & $\varnothing$ & $\varnothing$ & $\varnothing$ & $\varnothing$ \\
\hline Italy (28) & $\uparrow$ & $\varnothing$ & $\varnothing$ & $\varnothing$ & $\varnothing$ & $\varnothing$ & + & $\varnothing$ & $\varnothing$ & $\varnothing$ & $\varnothing$ & $\varnothing$ \\
\hline Italy (29) & $\uparrow$ & $\varnothing$ & $\downarrow$ & $172 / 198$ & $=$ & 10.3 & - & $=$ & $=$ & $=$ & $=$ & $\uparrow$ \\
\hline Ireland (30) & $\uparrow$ & $\varnothing$ & $=$ & $20 / 20$ & $+/-$ & 12.8 & - & $=$ & $\uparrow$ & $\uparrow$ & $\varnothing$ & $\uparrow$ \\
\hline Norway (31) & $\uparrow$ & $\varnothing$ & $\downarrow$ & $13 /-$ & $\varnothing$ & $\varnothing$ & $\varnothing$ & $\varnothing$ & $\varnothing$ & $\varnothing$ & $\varnothing$ & $\varnothing$ \\
\hline
\end{tabular}


and herbal foods. Folate and vitamin deficiencies have been observed to accompany hyperhomocysteinemia in inflammatory-autoimmune diseases other than psoriasis ${ }^{40}$. This coexistence has been explained by stating that folate and vitamin B12, which are very vulnerable to oxidation, may have been destroyed due to the oxidative stress caused by inflammation or that the molecules crucial for DNA synthesis and repair may have been depleted by the actively proliferating immune system cells ${ }^{40}$.

A positive correlation was found in at least half of the studies exploring the relationship between homocysteine level and severity of psoriasis as shown in Table 3. In other words, blood homocysteine level goes up as the severity of disease increases in some psoriatic patients. This correlation was observed in both some of the studies that found high homocysteine and those that did not. However, no such correlation was found in our study. This result may suggest that folic acid deficiency that occurs through fast keratinocyte cycle in the large body areas or through immune cell proliferation as in the proposition mentioned above could not be compensated in some psoriatic patients but could be compensated in some others. Such variations can be expected in a disease, the pathogenesis of which is multigenic and multifactorial. When we compared studies reporting normal homocysteine levels with those reporting high levels in patients with psoriasis, we observed that there was no significant difference in the severity of psoriasis (mean PASI: 10.7 vs. 10.0). The number of studies excluding subjects with a history CVD and those not excluding was also similar (Table 3). Therefore, the presence of higher homocysteine in some psoriatic patients does not seem to be explainable by inclusion of patients with more severe disease in these studies. Similarly, inclusion or exclusion of patients with a history of CVD probably cannot be an explanation of finding high versus normal homocysteine levels in patiens with psoriasis. The other factors causing elevated homocysteine such as obesity, diabetes and smoking were not dealt with in near half of studies in which high homocysteine was found. These conditions that often accompany psoriasis have the potential to contribute to the result.

Another point of concern in studies performed on psoriatic patients and involving homocysteine levels has been the genetic polymorphism of the MTHFR enzyme. Missense mutation that occurs when T localizes instead of $C$ in the $677^{\text {th }}$ nucleotide of the gene coding this enzyme leads to decreased enzyme activity. This enzyme enables conversion of homocysteine into methionine and formation of methyl donors that contribute to DNA methylation. Decreased enzyme activity results in elevation of plasma homocysteine levels ${ }^{46}$. The prevalence of MTHFR C677T polymorphism ranges between $20 \%$ and $55 \%$ in various populations ${ }^{47}$. The MTHFR C677T polymorphism in psoriasis patients has been studied in Turkey (47,48), Iran (36), China (37), Malaysia (49), Czech Republic (50), and in Australia (51) and different results have been obtained as was the case in blood homocysteine levels.

In China, where the first study on the subject was conducted, the prevalence of $\Pi$ genotype was found to be high in patients with psoriasis $(n=39)^{37}$. Similarly, the prevalence of $T$ allele containing genotypes was found to be significantly higher in psoriatic patients in Hatay $(n=96)$ and in Iran $(n=100)$ compared to controls ${ }^{36,48}$. It was shown in a study conducted in Istanbul in 60 patients without a control group that the blood homocysteine levels were high in the psoriatic patients with TT and CT genotypes ${ }^{47}$. However, the MTHFR gene polymorphisms in 310 psoriatic patients in Austria, 410 in the
Czech Republic and 200 in Malaysia did not show a genotype having more T alleles than in controls; on the contrary, the wild-type (CC) MTHFR genotype was more common in psoriatic patients in the Czech Republic $^{49-51}$. In Malaysia, the blood homocysteine level in patients with psoriasis from 3 different ethnicities (Chinese, Indian and Malaysian) was found to be similar to those in controls and the homocysteine level was observed to remain unaffected by polymorphism. In analyses carried out on the basis of ethnicity, the CT genotype frequency was found to be significantly higher than that in controls only in Malaysian psoriatic patients ${ }^{49}$. Although the MTHFR genotypes in psoriatic patients in Australia ( $n=310)$ did not differ from controls, the homocysteine level was found to be higher in 33 patients compared to that in controls ${ }^{51}$. Two meta-analyses carried out on the publications until 2014, which did not include any studies from our country, concluded that there was no relationship between psoriasis and MTHFR polymorphism ${ }^{52,53}$. In brief, both of the arguments stating that there was a different MTHFR polymorphism in patients with psoriasis than in healthy people and that there was a relationship between polymorphism and homocysteine are not conclusive findings.

\section{Conclusion}

The psoriatic patients in our study were found to have plasma homocysteine levels similar to that in controls falling within the rate of $40 \%$ in the other studies. Their folic acid, vitamin B6 and vitamin B12 values were also not different from healthy people. Due to its relationships with CVD, inflammation and autoimmunity, and DNA methylation with an epigenetic effect, homocysteine may be contributing to the disease pathogenesis in psoriasis and/or the pathogenesis of its comorbidities. However, as seen in differences in response to treatment, patients with psoriasis probably have heterogeneous genetic and epigenetic backgrounds and are exposed to different environmental factors. Therefore, patients with psoriasis who have been treated in our clinic may have had protection from homocysteine-elevating processes due to environmental factors and/or genetic basis. Further multicenter studies including large numbers of psoriatic patients with and without comorbidities that will investigate blood homocysteine values, measure homocysteine amount in psoriatic plaque and normal skin tissues, and investigate the effects of homocysteine on immunological pathways in patients with psoriasis may help us understand the possible role of homocysteine in psoriasis.

\section{Ethics}

Ethics Committee Approval: Local ethics committee approval was obtained for the study.

Informed Consent: A consent form was completed by all participants. Peer-review: Externally and Internally peer-reviewed.

\section{Authorship Contributions}

Surgical and Medical Practices: M.U., Concept: M.U., E.Ş., N.Ş., G.K., A.K., Design: M.U., D.K., C.G., Data Collection or Processing: M.U., A.K., D.K., C.G., Analysis or Interpretation: M.U., I.K.Ö., Literature Search: M.U., E.Ş., G.K., N.Ş., Writing: M.U.

Conflict of Interest: No conflict of interest was declared by the authors.

Financial Disclosure: The authors declared that this study received no financial support. 


\section{References}

1. Gelfand JM, Neiman AL, Shin DB, Wang X, Margolis DJ, Troxel AB: Risk of myocardial infarction in patients with psoriasis. JAMA 2006;296:1735-41.

2. Mallbris L, Akre $\mathrm{O}$, Granath F, et al: Increased risk for cardiovascular mortality in psoriasis inpatients but not in outpatients. Eur J Epidemiol 2004;19:225-30.

3. Samarasekera EJ, Neilson JM, Warren RB, Parnham J, Smith CH: Incidence of cardiovascular disease in individuals with psoriasis: a systematic review and metaanalysis. J Invest Dermatol 2013;133:2340-6.

4. Ryan C, Kirby B: Psoriasis is a systemic disease with multiple cardiovascular and metabolic comorbidities. Dermatol Clin 2015:33:41-55.

5. Kremers HM, McEvoy MT, Dann FJ, Gabriel SE: Heart disease in psoriasis. J Am Acad Dermatol 2007;57:347-54.

6. Ray JG: Meta-analysis of hyperhomocysteinemia as a risk factor for venous thromboembolic disease. Arch Intern Med 1998;158:2101-6.

7. Eikelboom JW, Lonn E, Genest J Jr, Hankey G, Yusuf S: Homocyst(e)ine and cardiovascular disease: a critical review of epidemiologic evidence. Ann Intern Med 1999:131:363-75.

8. Nygard O, Nordrehaug JE, Refsum H, Ueland PM, Farstad M, Wollset SE: Plasma homocysteine levels and mortality in patients with coronary artery disease. N Engl J Med 1997;337:230-6.

9. Graham IM, Daly LE, Refsum HM, et al: Plasma homocysteine as a risk factor for vascular disease. The European concerted action project. JAMA 1997;277:1775-81.

10. Boushey CJ, Beresford SA, Omenn GS. Motulsky AG: A quantitative assessment of plasma homocysteine as a risk factor for vascular disease. JAMA 1995;274:1049-57.

11. Ganguly P, Alam SF: Role of homocysteine in the development of cardiovascular disease. Nutrition J 2015;14:6.

12. Nygard O, Vollset SE, Refsum H, Brattsröm L, Ueland PM: Total homocysteine and cardiovascular disease. J Intern Med 1999;246:425-54.

13. Akcali C, Buyukcelik B, Kirtak N, Inaloz S: Clinical and laboratory parameters associated with metabolic syndrome in Turkish patients with psoriasis. J Int Med Res 2014;42:386-94

14. Erturan I, Köroğlu BK, Adiloğlu A, et al: Evaluation of serum SCD40L and homocysteine levels with subclinical atherosclerosis indicators in patients with psoriasis: a pilot study. Int J Dermatol 2014:53:503-9.

15. Liew SC, Das-Gupta E, Wong SF, Lee N, Safdar N, Jamil A: Association of methylenetetrahydrofolate reductase (MTHFR) 677 C > T gene polymorhism and homocysteine levels in psoriasis vulgaris patients from Malaysia: a casecontrol study. Nutr J 2012;11:1.

16. Romani J, Caixas A, Carrascosa JM, Ribera M, Rigla M, Luelmo J: Effect of narrowband ultraviolet $\mathrm{B}$ therapy on inflammatory markers and body fat composition in moderate to severe psoriasis. Br J Dermatol 2012;166:1237-44.

17. Ataseven A, Kesli R, Kurtipek GS, Ozturk P: Assesment of Lipocalin 2. Clusterin, Soluble Tumor Necrosis factor receptor-1, interleukin-6, homocysteine and uric acid levels in patients with psoriasis. Dis Markers 2014;2014:541709.

18. Cakmak SK, Gül U, Kiliç C, Gönül M, Soylu S, Kiliç A: Homocysteine, vitamin B12 and folic acid levels in psoriasis patients. J Eur Acad Dermatol Venereol 2009:23:300-3.

19. Bilgiç R, Yıldız H, Karabudak Abuaf Ö, İpçioğlu OM, Doğan B: Psoriasis hastalarında serum asimetrik dimetilarjinin düzeylerinin değerlendirilmesi. Turkderm 2015:49:13-8

20. Karabacak E, Aydin E, Ozcan O et al: Methylentetrahydrofolate reductase (MTHFR) 677 C $>$ T gene polymorphism as a possible factor for reducing clinical severity of psoriasis. Int J Clin Exp Med 2014;7:697-702.

21. Karabudak O, Ulusoy RE, Erikci AA, Solmazgul E, Dogan B, Harmanyer Y: Inflammation and hypercoagulable state in adult psoriatic men. Acta Dermato Venereol 2008;88:337-40

22. Vanizor Kural B, Orem A, Cimşit G, Uydu HA, Yandi YE, Alver A: Plasma homocysteine and its relationships with atherothrombotic markers in psoriatic patients. Clin Chim Acta 2003;332:23-30.

23. Didar Balcı D, Yönden Z, Doğramacı ÇA, Duran N: Hafif ve orta şiddetli psoriyazis hastalarında serum yüksek sensitif $C$ reaktif protein ve homosistein düzeyleri. Turkderm 2009;43:53-7.

24. Bilgiç Ö, Altınyazar HC, Baran H, Ünlü A: Serum homocysteine, asymmetric dimethyl arginine (ADMA) and other arginine-NO pathway metabolite levels in patients with psoriasis. Arch Dermatol Res 2015;307:439-44.

25. Giannoni M, Consales V, Campanati A, et al: Homocysteine plasma levels in psoriasis patients: Our experience and review of the literature. J Eur Acad Dermatol Venereol 2015;29:1781-5

26. Malerba M, Gisondi P, Radaeli A, Sala R, Calzavara Pinton PG, Girolomoni $\mathrm{G}$ : Plasma homocysteine and folate levels in patients with chronic plaque psoriasis. Br J Dermatol 2006;155:1165-9.
27. Brazzelli V, Grasso V, Fornara L, et al: Homocysteine, vitamin B12 and folic acid levels in psoriatic patients and correlation with disease severity. Int Immunopathol Pharmacol 2010;23:911-6.

28. Richetta AG, Mattozzi C, Macaluso L, et al: Homocysteine plasmatic status in patients with psoriasis. Eur J Dermatol 2011;21:621-3.

29. Gisondi P, Malerba M, Malara G, et al: C-reactive protein and markers for thrombophilia in patients with chronic plaque psoriasis. Int J Immunopathol Pharmacol 2010;23:1195-202

30. Tobin AM, Hughes R, Hand EB, Leong T, Graham IM, Kirby B: Homocysteine status and cardiovascular risk factors in patients with psoriasis: a casecontrol study. Clin Exp Dermatol 2011;36:19-23.

31. Refsum H, Helland S, Ueland PM: Fasting plasma homocysteine as a sensitive parameter of antifolate effect: a study of psoriasis patients receiving lowdose methotrexate treatment. Clin Pharmacol Ther 1989;46:510-20.

32. Mandaviya PR, Stolk L, Heil SG: Homocysteine and DNA methylation: a review of animal and human literature. Mol Genet Metab 2014;113:243-52.

33. Chandra A, Ray A, Senapati S, Chatterjee R: Genetic and epigenetic basis of psoriasis pathogenesis. Mol Immunol 2015;64:313-23.

34. Baiqiu W, Songbin F, Guiyin Z, Pu L: Study of the relationship between psoriasis and the polymorphic site C677T of methylenetetrahydrofolate reductase. Chin Med Sci J 2000;15:119-20.

35. Zhou S, Zhang Z, Xu G: Notable epigenetic role of hyperhomocysteinemia in atherosclerosis. Lipids Health Dis 2014;13:134.

36. Asefi M, Vaisi-Raygani A, Khodarahmi $R$, et al: Methylentetrahydrofolatereductase (rs 1801133) polymorphism and psoriasis: contribution to oxidative stress, lipid peroxidation and correlation with vascular adhesion protein 1, preliminary report. J Eur Acad Dermatol Venereol 2014;28:1192-8.

37. Baiqiu W, Songbin F, Guiyin Z, Pu L: Study of the relationship between psoriasis and the polymorphic site C677T of methylenetetrahydrofolate reductase. Chin Med Sci J 2000;15:119-20.

38. Krajcovicová-Kudlácková M, Blazícek P, Kopcová J, Béderová A, Babinská $\mathrm{K}$ : Homocysteine levels in vegetarians versus omnivores. Ann Nutr Metab 2000:44:135-8.

39. Kang SS, Wong PW, Malinow MR: Hyperhomocyst(e)inemia as a risk factor for occlusive vascular disease. Annu Rev Nutr 1992;12:279-98.

40. Lazzerini PE, Capecchi PL, Selvi E, et al: Hyperhomocysteinemia, inflammation and autoimmunity. Autoimmun Rev 2007;6:503-9.

41. Dawson H, Collins G, Pyle R, Deep-Dixit V, Taub DD: The immunoregulatory effects of homocysteine and its intermediates on T-lymphocyte function. Mech Ageing Dev 2004;125:107-10.

42. Schroecksnadel K, Frick B, Wirleitner B, Schennach H, Fuchs D: Homocysteine accumulates in supernatants od stimulated human peripheral blood mononuclear cells. Clin Exp Immunol 2003;134:53-6.

43. Scarpa R, Manguso F, D'Arienzo A, et al: Microscopic inflammatory changes in colon of patients with both active psoriasis and psoriatic arthritis without bowel symptoms. J Rheumatol 2000;27:1241-6.

44. Schatteman L, Mielants H, Veys EM, et al: Gut inflammation in psoriatic arthritis: a prospective ileocolonoscopic study. J Rheumatol 1995;22:680-3.

45. https://www.bda.uk.com/foodfacts/FolicAcid.pdf

46. Liew SC, Gupta ED: Methylenetetrahydrofolat reductase (MTHFR) C677T polymorphism: epidemiology, metabolism and associated diseases. Eur J Med Genet 2015;58:1-10.

47. Karabacak E, Aydın E, Ozcan O, et al: Methylentetrahydrofolate reductase (MTHFR) 677 C>T gene polymorphism as a possible factor for reducing clinical severity of psoriasis. Int J Clin Exp Med 2014;7:697-702.

48. Izmirli $M$, Sen $B B$, Rifaioglu $E$, et al: Methylenetetrahydrofolate reductase (MTHFR) C6777T polymorphism in psoriasis in southern Turkey. An Bras Dermatol 2016:91:611-3.

49. Liew SC, Das-Gupta E, Wong SF, Lee N, Safdar N, Jamil A: Association of methylenetetrahydrofolate reductase (MTHFR) 677 C > T gene polymorphism and homocysteine levels in psoriasis vulgaris patients from Malaysia: a casecontrol study. Nutrition J 2012;11:1

50. Vasku V, Bienertova-Vasku J, Necas M, Vasku A: MTHFR (methylenetetra hydrofolate reductase) C677T polymorphism and psoriasis. Clin Exp Med 2009;9:327-31.

51. Weger W, Hofer A, Stanger $O$, et al: The methylenetetrahydrofolate reductase $677 C>T$ gene polymorphism is not associated with chronic plaque psoriasis. Exp Dermatol 2008;17:748-51

52. Wu D, Shi D, Yang L, Zhu X: Association between methylenetetrahydrofolate reductase C677T polymorphism and psoriasis: A meta analysis. J Dermatol 2016:43:162-9.

53. Qi JH, Qi JH, Shi N, Chen YJ, Nie G: Association between MTHFR 677C/T polymorphism and psoriasis risk: a meta analysis. Genet Mol Res 2015;14:3869-76 